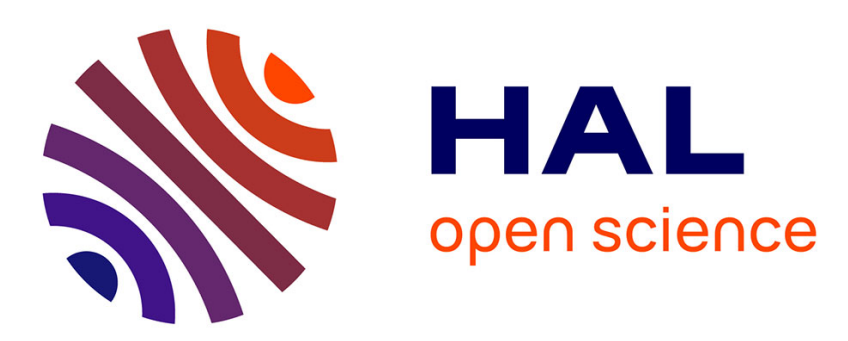

\title{
Detection of environmental mutagens using the FACIM assay
}

J. Couteau, J-M. Flaman, C. Minier, J. Cachot

\section{To cite this version:}

J. Couteau, J-M. Flaman, C. Minier, J. Cachot. Detection of environmental mutagens using the FACIM assay. Marine Environmental Research, 2008, 66 (1), pp.62. 10.1016/j.marenvres.2008.02.023 . hal-00501946

\section{HAL Id: hal-00501946 \\ https://hal.science/hal-00501946}

Submitted on 13 Jul 2010

HAL is a multi-disciplinary open access archive for the deposit and dissemination of scientific research documents, whether they are published or not. The documents may come from teaching and research institutions in France or abroad, or from public or private research centers.
L'archive ouverte pluridisciplinaire HAL, est destinée au dépôt et à la diffusion de documents scientifiques de niveau recherche, publiés ou non, émanant des établissements d'enseignement et de recherche français ou étrangers, des laboratoires publics ou privés. 


\section{Accepted Manuscript}

Detection of environmental mutagens using the FACIM assay

J. Couteau, J-M. Flaman, C. Minier, J. Cachot

PII:

S0141-1136(08)00034-2

DOI:

10.1016/j.marenvres.2008.02.023

Reference:

MERE 3186

To appear in:

Marine Environmental Research

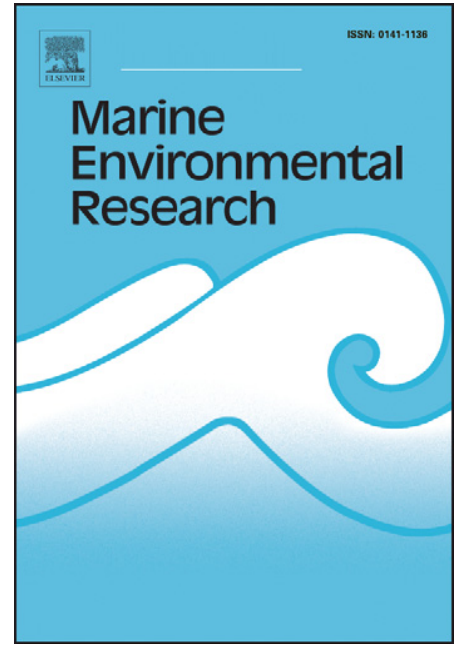

Please cite this article as: Couteau, J., Flaman, J-M., Minier, C., Cachot, J., Detection of environmental mutagens using the FACIM assay, Marine Environmental Research (2008), doi: 10.1016/j.marenvres.2008.02.023

This is a PDF file of an unedited manuscript that has been accepted for publication. As a service to our customers we are providing this early version of the manuscript. The manuscript will undergo copyediting, typesetting, and review of the resulting proof before it is published in its final form. Please note that during the production process errors may be discovered which could affect the content, and all legal disclaimers that apply to the journal pertain. 


\title{
Detection of environmental mutagens using the FACIM assay
}

\author{
J. Couteau ${ }^{\text {a } * \text {, J-M. Flaman }}{ }^{\text {b }}$, C. Minier ${ }^{\text {a }}$, J. Cachot ${ }^{\text {a }}$ \\ ${ }^{a}$ LEMA, EA-3222, IFRMP 23, University of Le Havre, 76058 Le Havre cedex, France \\ ${ }^{b}$ INSERM U614, IFRMP 23, Faculty of Medicine, 76183 Rouen cedex, France
}

\begin{abstract}
A genetically engineered diploid yeast strain named $\mathrm{yJC}^{2}$, was specifically developed for environmental mutagen detection and characterization of induced mutations. This strain contains one copy of the human TP53 tumour suppressor gene coding sequence which is used as a molecular target for mutagens and two copies of the $A D E 2$ reporter gene allowing accurate measurement of the TP53 transcriptional activity. The strain sensitivity to mutagens was evaluated by exposing cells to UVC, 4-nitroquinoline (NQO) or to an organic extract of sediment from the Seine estuary. For all studied mutagens, a significant and dose-dependent increase of mutant frequency was observed. The present assay named FACIM II (Functional Analysis of Chemical-Induced TP53 Mutations) is more convenient than the FACIM I and more inducible than the SOS Chromotest to detect direct-acting mutagens in the environment.
\end{abstract}

Keywords : Yeast; In vitro mutagenesis assay; UV; NQO; Sediment organic extract

*Corresponding author: Tel: 332327443 90; fax: 33232744314 
Email address: jerome.couteau@univ-lehavre.fr (J. Couteau)

In the aquatic environment, living organisms are exposed to complex mixtures of pollutants, some are potent mutagen including polycyclic aromatic hydrocarbons (PAHs), organic solvents and aromatic amine, etc (Watenabe et al., 2005; Cachot et al., 2006). These compounds can induce DNA damage which may lead to deleterious or heritable mutations, cancer or embryo lethality. It has been shown that co-exposure to UV can potentiate toxicity of certain mutagens such as PAH to aquatic larvae (Peachey, 2005). Detection of environmental mutagens is thus a major issue for preservation of natural ecosystems. Accordingly a new assay named FACIM II was specifically designed to assess mutagenicity of chemicals or radiations and to allow identification of induced mutations at the TP53 locus.

An in vitro version of the FACIM assay was previously developed (Cachot et al., 2004). In the present assay the human TP53 tumour suppressor gene cDNA as well as two functional copies of the reporter $A D E 2$ gene under the transcriptional control of the TP53 protein were integrated into the genome of a diploid yeast strain by gap repair. The TP53 cDNA serves as a molecular target for mutagens while the reporter system allows accurate evaluation of the TP53 functional status. Yeasts expressing a mutant form of the TP53 protein are unable to activate expression of the $A D E 2$ reporter gene. After plating onto an adenine-depleted medium, mutant $\mathrm{ADE}^{-}$mutant colonies turn red or pink due (no activation or impaired activation at the reporter gene) to accumulation of an intermediate in adenine biosynthesis while wild-type $\mathrm{ADE} 2^{+}$colonies are white.

For UV exposure, $\mathrm{yJC}^{2}$ cells were grown to $\log$ phase $\left(\mathrm{A}_{600 \mathrm{~nm}}\right.$ of 0.4$)$ and then plated onto selective solid medium. Plates were then exposed to $254 \mathrm{~nm}$ UV C radiations generated from a germicidal lamp (Bioblock) for $0,106,213,320$ and $426 \mathrm{~J} / \mathrm{m}^{2}$. For exposure to 4- 
nitroquinoline-1-oxide (NQO) or organic extract, $\mathrm{yJC}^{2}$ cells were grown up to log phase in an appropriate selective medium and were then exposed for 2 hours to $0-520 \mathrm{nM}$ of NQO or to $1 \%(\mathrm{v} / \mathrm{v})$ DMSO. Three replicates were performed for each treatment condition. After four days of culture at $30^{\circ} \mathrm{C}$ and one more day at $4{ }^{\circ} \mathrm{C}$ (for colour development), red, pink and white colonies were counted in each plate. Mutant frequencies were calculated by dividing the number of red and pink colonies by the total number of colonies. Yeast cell survival was determined by calculating the ratio of the total number of colonies in each assay to the total number of colonies in control plates. Results were compared to the SOS developed by Quillardet and Hofnung (1996).

Following exposure to UVC a significant and dose-dependent increase in mutant frequency and decrease of cell survival were observed (Fig. 1A). The mutant frequency was always significantly $(\mathrm{p}<0.005)$ above the background level, except with the lowest UV dose $\left(106 \mathrm{~J} / \mathrm{m}^{2}\right)$. At the highest tested dose $\left(426 \mathrm{~J} / \mathrm{m}^{2}\right)$, a 79 -fold increase in mutant frequency over the background level was observed. In the meantime cell survival decreased 6-fold. Using the haploid yeast indicator yeast strain yIG397 and an in vitro exposure protocol, Moshinsky and Wogan (1997) and Inga et al. (1998) reported a 17 to 18 -fold increase of mutant frequencies following exposure to $300 \mathrm{~J} / \mathrm{m}^{2}$ of UVC.

Following exposure to NQO a significant and dose-dependent decrease in cell survival and increase in mutant frequency were observed (Fig. 1B). All treatments except the lowest NQO concentration $(0.005 \mu \mathrm{M})$ induced a significant $(\mathrm{p}<0.005)$ increase of mutant frequencies in comparison to DMSO-exposed cells. At the higher test concentration $(0.5 \mu \mathrm{M})$ a 78-fold increase of mutant frequency and a 18-fold decrease of cell survival were observed. At the same NQO concentration and using a micro-plate version of the SOS Chromotest (White et al., 1996), a 8-fold increase of the SOS induction factor (IF) was observed (data not 
shown). In the meantime, limits of detection for both tests were very close, $0.016 \mu \mathrm{M}$ and $0.025 \mu \mathrm{M}$ for the SOS Chromotest and the FACIM II, respectively.

The genotoxic potency of a crude organic extract of sediments collected in Oissel (Seine estuary, France) in June 2005 (Cachot et al., 2006) was evaluated using both the SOS Chromotest (Quillardet and Hofnung, 1985) and the FACIM II. Concordant results were obtained with both tests. A clear dose-dependent increase of the SOS IF (Fig. 2A) and the mutant frequency (Fig. 2B) were observed. The maximum SOS IF achieved 1.7 while the mutant frequency increased 3-fold in comparison to the control solvent. These positive responses were obtained without addition of a $\mathrm{S} 9$ fraction indicating that this sediment sample contained organic pollutants with direct genotoxic activity. A previous study has already shown that sediments from the upper Seine estuary were genotoxic (Cachot et al., 2006) but this the first evidence of the presence of direct-acting mutagens. These preliminary results suggest that the FACIM II represent a sensitive bioassay to evaluate mutagenicity of directacting mutagens either pure or in complex mixture. This assay could also allow identification of mutations and characterization of mutation spectra induced by different classes of mutagens. Finally it was demonstrated that sediments from the upper Seine estuary contain direct-acting mutagens, which may represent a threat to aquatic species living in this area.

\section{Acknowledgements}

This study was supported by the French National Program of Ecotoxicology (PNETOX III) and the Seine-Normandy Water Agency.

\section{References}

Watenabe, T., Ohe, T., and Hirayama, T. (2005). Environmental Sciences, 12, 325-346. 
Cachot, J., Geffard, O., Augagneur, S., Lacroix, S., Le Menach, K., Peluhet, L., et al. (2006). Aquatic Toxicology, 79, 257-267.

Peachey, R.B.J. (2005). Journal of Experimental Marine Biology and Ecology, 315, 103-114.

Cachot, J., Couteau, J., Frebourg, T., Leboulenger, F., and Flaman. J.M. (2004). Mutation Research, 552, 51-60.

Moshinsky, D., and Wogan, G.(1997). Proceedings of the National Academy of Sciences USA, 94, 2266-2271.

Inga, A., Scott, G., Monti, P., Aprile, A., Abbondandolo, A., Burns, P., et al. (1998). Carcinogenesis, 19, 741-746.

White, P.A., Rasmusen, J.B., and Blaise, C. (1996). Mutation Research, 360, 51-74.

Quillardet, P., and Hofnung, M. (1985). Mutation Research, 147, 65-78. 


\section{Figure captions}

Fig. 1. Mutant frequencies and cell survival for diploid $\mathrm{yJC}^{2}$ yeast cells exposed to several doses of $254 \mathrm{~nm}$ UVC radiations (A) or several concentrations of NQO (B).

Fig. 2. Genotoxic activity of a sediment organic extract from the upper Seine estuary measured using either the SOS Chromotest (a) or the FACIM II assay (b). SOS Chromotest was performed as described by Quillardet and Hofnung [7] without S9 addition. 
Figure 1

a)

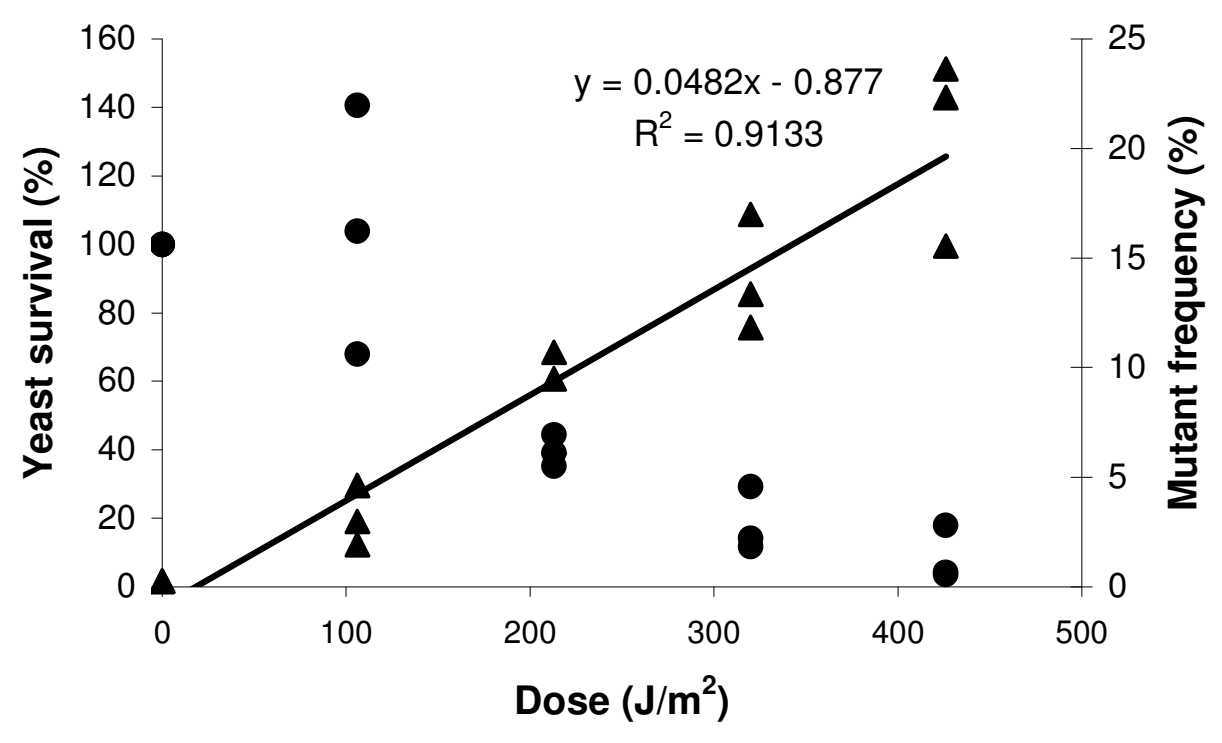

- Yeast survival $\Delta$ Mutant frequency - Linear regression

b)

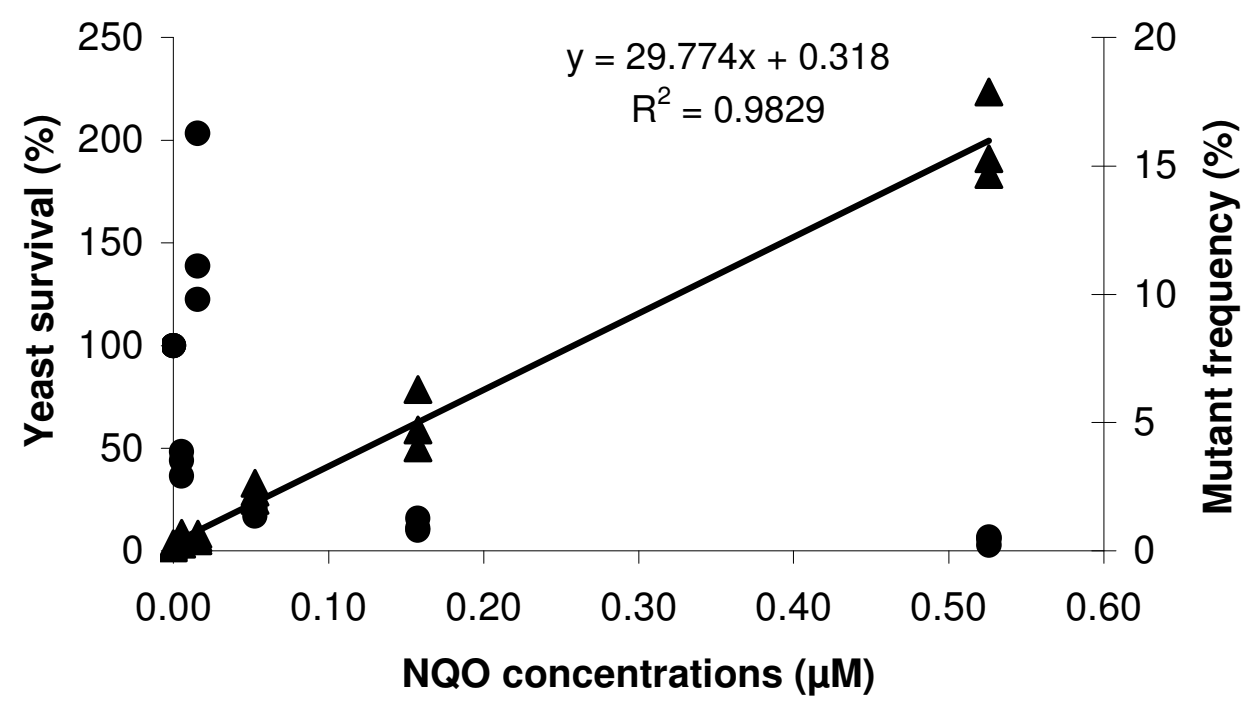

- Yeast survival $\Delta$ Mutant frequency - Linear regression 
Figure 2

a)

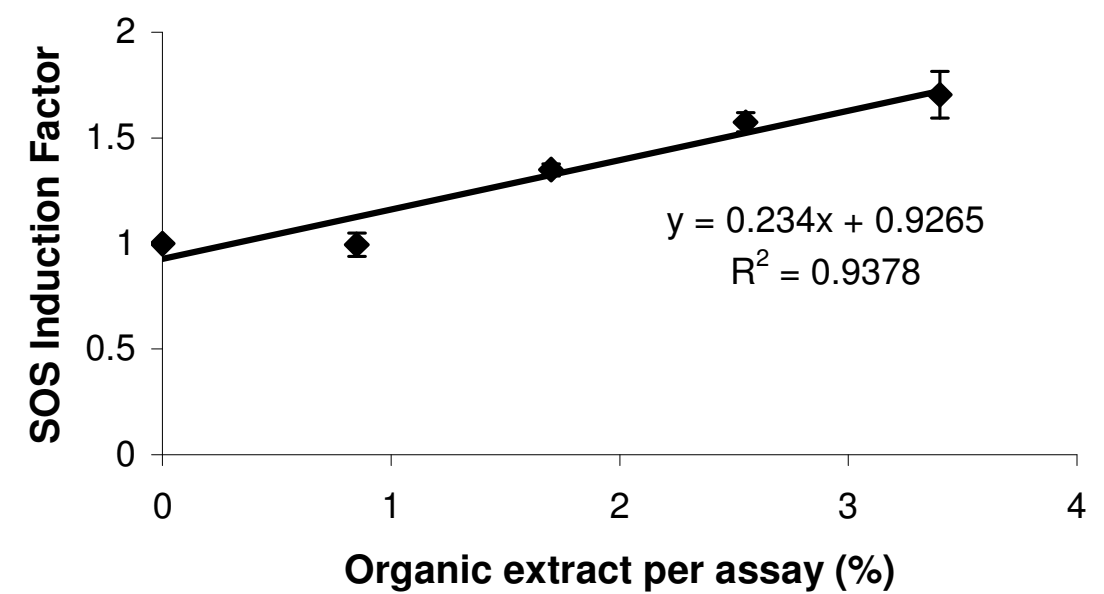

__ Linear regression

b)

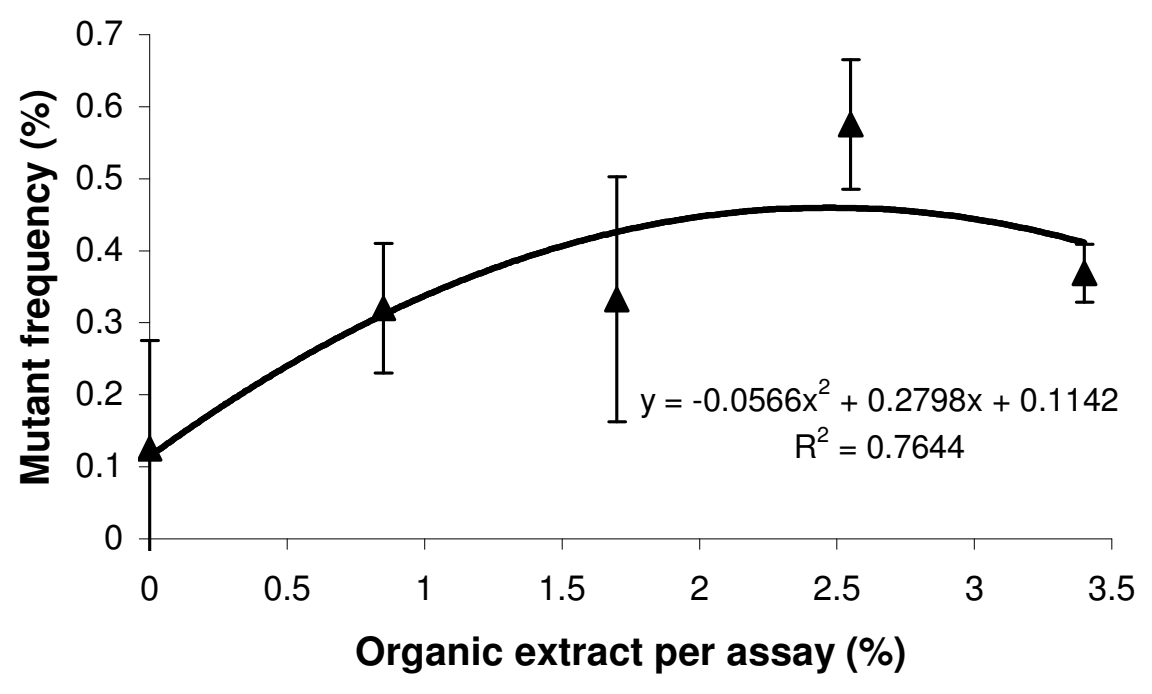

polynomial regression 